\title{
A case report of multiple fractures with arterial vasospasm associated with ergotamine use
}

\author{
Abdullah Küçükalp, M.D., ${ }^{1}$ Kemal Durak, M.D., ${ }^{2}$ Muhammet Sadık Bilgen, M.D. ${ }^{2}$ \\ ${ }^{1}$ Department of Orthopedics and Traumatology, Sussehri State Hospital, Sivas \\ ${ }^{2}$ Department of Orthopedics and Traumatology, Uludag University Faculty of Medicine, Bursa
}

\begin{abstract}
Vasospasm that develops in association with ergotamine use is a rarely seen but well-understood complication. A case is presented here of multiple fractures in which arteriospasm affecting all the arteries of the lower limb on the same side occurred 10 days posttrauma. In this case, the arteriospasm resulting from ergotamine addiction and high doses of ergotamine, which may be confused with post-traumatic angiospasm, was treated with a marcaine infusion by epidural catheter and heparin, iliomedin and nitronal infusion intravenously. This clinical condition should be borne in mind for all trauma cases determined to have arterial vasospasm, and the use of ergotamine must be queried when taking the anamnesis from the patient.
\end{abstract}

Key words: Ergotamine addiction, migraine, multiple fractures, vasospasm.

\section{INTRODUCTION}

Non-atherosclerotic causes of acute leg ischemia, such as traumatic vasospasm, arteritis, conditions that accelerate clotting, compartment syndrome, artery dissection, and arterial pressure as in popliteal cysts, are side effects associated with medications. Particularly when high doses of ergotamine derivatives are used alone or together with certain other medications, the increased effect on the blood may lead to arterial vasospasm.

The pathophysiology of traumatic angiospasm is unknown, but is thought to be a normal response to pain and venous stasis. ${ }^{[1,2]}$ Post-traumatic vasospasm is one of the body's protective reactions. However, if the whole arterial tree of the extremity is affected, trophic changes, fibrosis and clinical changes resembling Volkmann ischemic contracture may occur in the extremity. ${ }^{[3]}$

Ergotamine is an alkaloid produced from fungi, which ac-

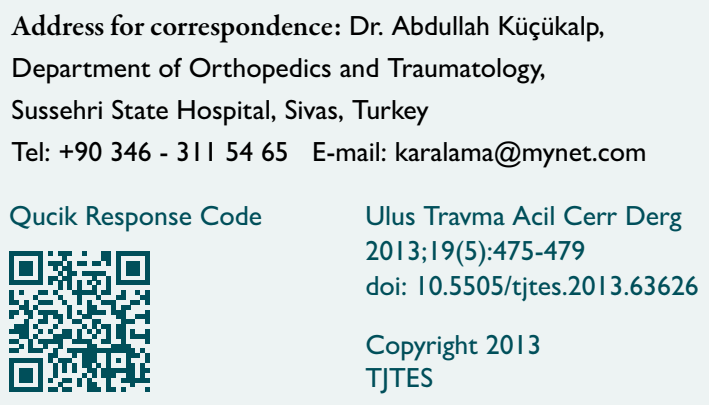

tivates the sympathetic nervous system and is used in the treatment of migraines. ${ }^{[4-6]}$ Ergot alkaloids affect $\alpha$-receptors, dopamine receptors and 5-HT (serotonin) receptors. [7,8] Although ergotamine-induced ischemia is seen rarely, it can lead to the serious complications of vasospasm and thrombosis. Toxicity may occur from doses used for chronic treatment, following high doses in acute cases, and in highly sensitive patients. ${ }^{[9-11]}$ This condition, known as ergotism, may affect coronary, mesenteric, renal, and extremity arteries. $^{[12]}$

We present here a case in which, as a result of high-dosage use of ergotamine, arterial vasospasm developed in the same side lower extremity 10 days post-trauma (displaced hip, Pipkin type I femoral head fracture and Gustilo-Anderson type 3a Schatzker type 6 tibial plateau fracture).

\section{CASE REPORT}

On Sunday, 13 December, at approximately 4:00 p.m., a 46-year-old male was taken to Tekirdağ Çorlu State Hospital after having been involved in a traffic accident. The patient had left-side hip dislocation, Pipkin type I femoral head fracture, Gustilo-Anderson type 3a open Schatzker type 6 tibial plateau fracture, and an avulsion fracture of the tibial tuberosity, and he was taken for surgery (Fig. Ia-e).

Closed reduction was performed for the left hip dislocation; following debridement, the wound was sutured and supracondylar skeletal traction was applied. A full leg plaster was applied, and the patient was monitored in the intensive care unit. One day later, he was moved to the Orthopedic and 
Traumatology Clinic, and on the second day, at the patient's request, he was transferred to the Orthopedic and Traumatology Clinic of Uludağ University Medical Faculty. From the patient anamnesis, there was no chronic disease or regular use of any medication. In the physical examination, a sutured wound approximately $12 \mathrm{~cm}$ in length was seen on the medial left knee. Motor and sensory examination was determined as normal in the lower extremity. Peripheral arteries could be palpated by hand. On the same day, plain radiographs were taken. Arterial Doppler ultrasonography (USG) of the left lower extremity and computerized tomography (CT) images of the pelvis and left knee were taken. No pathology was determined from the USG (Fig. If).

After six days of traction $(7 \mathrm{~kg})$ and wound care, Doppler USG was taken due to widespread pain in the left lower extremity; the distal left knee was cold and pale, and the peripheral arteries could not be palpated (Fig. 2a). Blood flow in the tibialis posterior artery and the dorsalis pedis veins could not be encoded in the Doppler USG. The skeletal traction was terminated.

An emergency cardiovascular surgical consultation was requested for the patient. From the cardiovascular surgical evaluation, an emergency angiograph was administered. The angiograph results determined widespread arterial spasm starting from the proximal femoral artery in the left lower extremity (Fig. 2b-d). When arterial vasospasm was seen on the 10th day post-trauma, traumatic vasospasm was considered as a priority. The patient anamnesis was examined in greater depth, and it was revealed that, for 10 years, the patient had been taking $4-5$ ergotamine tartrate $(0.75 \mathrm{mg})$ tablets daily in an irregular and uncontrolled manner. This medication was immediately ceased.

Treatment recommended by the cardiovascular surgical department was started: intravenous (IV) glycerol trinitrate (20 cc $(20 \mathrm{mg})$ glycerol trinitrate $+30 \mathrm{cc} 0.9 \% \mathrm{NaCl}) 2 \mathrm{cc} /$ hour, IV heparin infusion (5 cc heparin (25000 IU) +45 cc $0.9 \% \mathrm{NaCl}$, activated partial thromboplastin time (aPTT) value 60-80) and iloprost tromethamine (iloprost tromethamine $20 \mathrm{mcg} /$ $\mathrm{ml}+100 \mathrm{cc} 0.9 \% \mathrm{NaCl}) 5 \mathrm{cc} / \mathrm{s}$ (for 10 days). Heat was applied locally to the left lower extremity, and the Algology Department was consulted with respect to sympathetic system blockage. On the same day, the Algology Department started the administration of $40 \mathrm{cc}$ bupivacaine hydrochloride $(5 \mathrm{mg} /$ $\mathrm{ml})$ and $10 \mathrm{cc}$ fentanyl $(0.05 \mathrm{mg} / \mathrm{ml})$, in a $1 \mathrm{l} 0 \mathrm{cc} 0.9 \% \mathrm{NaCl}-$ prepared solution at $5 \mathrm{cc}$ bolus/hour via epidural catheter. This infusion was continued for approximately 10 days, during which time the findings of ischemia receded, the peripheral arteries again became palpable, and the coldness and pallor of the lower extremity resolved (Fig. 2e).
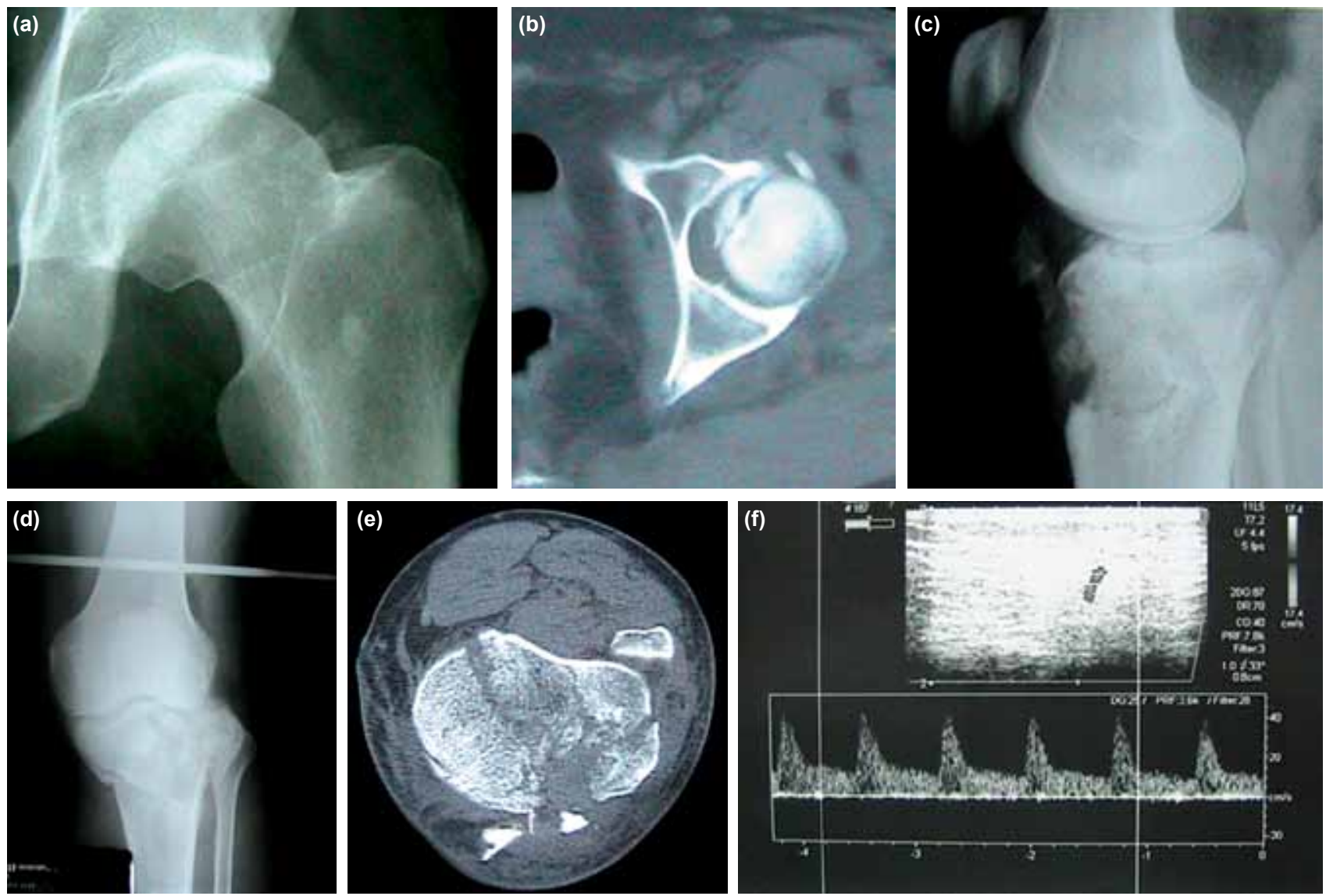

Figure 1. (a, b) Pipkin type 1 femoral head fracture. (c-e) Tibial plateau fracture. (f) Arterial Doppler USG. 
The heparin infusion administered to the patient was stopped on 2 December $201 \mathrm{l}$, and enoxaparin-natrium $2 \times 40 \mathrm{mg}$ was started. After removing the sutures in the medial left knee, the patient underwent surgery on 12 December 201I. An anterolateral incision was made to the proximal tibia, and the extensor mechanism was repaired with number 5 non-absorbable polyfilament suture. After reduction of the plateau fracture, fixation was done using a tibial plate (Fig. 2f, g).

There were no perioperative complications. On evaluation by the cardiovascular surgeon, it was recommended to continue the existing treatment without any additions. When the patient was observed to be stable and the findings of ischemia had completely receded, he was discharged with the recommendation of following foot stretching and strengthening exercises.

\section{DISCUSSION}

Fractured hip dislocations and tibial plateau fractures are often associated with severe soft tissue damage, and open fractures occur in many cases. ${ }^{[13]}$ As the injuries arise from highenergy trauma, there is a high risk of vascular nerve damage
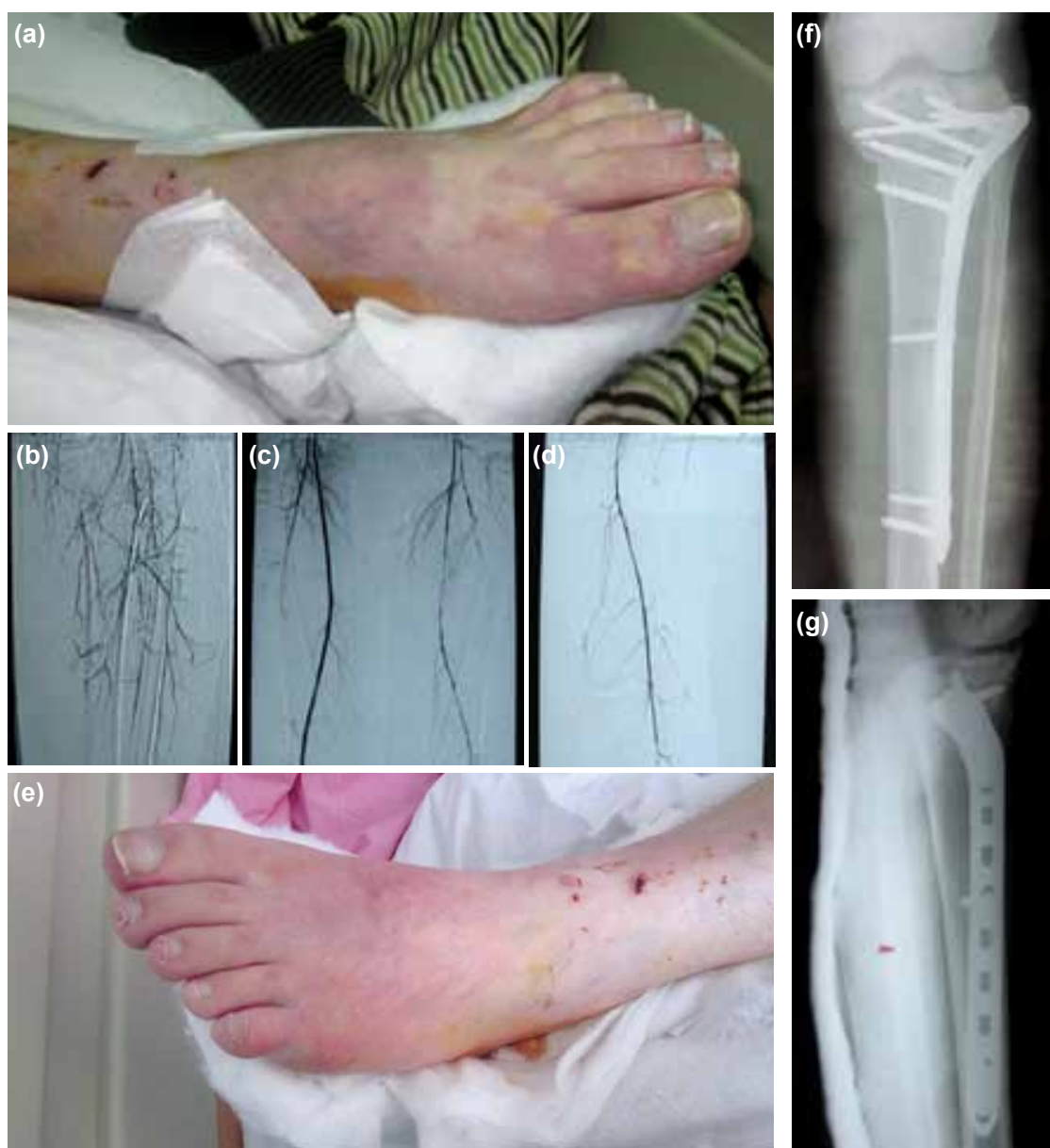

Figure 2. (a) Ischemic changes in the left foot. (b-d) Angiograph showing widespread arterial vasospasm in the left lower extremity. (e) The left foot after treatment. (f, g) Fixation of the tibial plateau fracture. or compartment syndrome. Together with pulse evaluation, it is necessary to clinically examine the leg for findings of ischemia. The absence or reduction of a pulse, spreading hematoma, advanced swelling, continued arterial bleeding, and damage to anatomically related nerves are indications for arteriography. ${ }^{[14]}$ The pathophysiology of traumatic angiospasm is not known, but is thought to be the normal response to pain and venous stasis. In fractures and non-weight-bearing feet, this physiological vasomotor reflex may lead to coldness and cyanosis in the lower extremity. ${ }^{[2]}$

When peripheral pulses cannot be taken, circulation in the distal arteries should be evaluated by Doppler USG. This is particularly useful for distal pulses that are difficult to feel in vasospasm. ${ }^{[15]}$

In the current case, although no vascular pathology was determined by Doppler USG and physical examination immediately post-trauma, on the 10th day, acute arterial occlusion was considered due to the development of pain, coldness and pallor and because blood flow could not be encoded in the tibialis posterior and dorsalis pedis veins from the Doppler USG. An angiograph was taken, which determined widespread vasospasm from the proximal femoral artery extending to the distal arteries. Differential diagnoses of Buerger disease and Raynaud phenomenon were considered because of the angiographic images, but the clinical table and the angiographic findings differed from that of diffuse spasm. ${ }^{[16]}$ The occlusion in the leg arteries in Buerger disease is seen as collateral formation, with the occlusion extending in a corkscrew fashion along the arteries. The occlusion in the proximal arteries was normal and widespread spasm was not seen. Raynaud phenomenon is more often seen in upper extremity arteries and usually responds to the application of intra-arterial vasodilator. Generally, the symptoms do not cause an acute deterioration. ${ }^{[17]}$ In the current case, as arterial vasospasm occurred on the 10th day, and the diagnosis of traumatic vasospasm was made. When the anamnesis was examined in greater depth, it was learned that, for approximately 10 years, the patient had been taking 4-5 tablets ergotamine tartrate $(0.75 \mathrm{mg})$ daily due to migraine in an irregular and uncontrolled manner. 
Migraine is seen as one or two headache attacks per week. It is thought that patients who experience headaches daily and feel the need for ergotamine derivatives for relief become addicted to ergotamine. In this clinical situation, patients find themselves in a vicious circle of taking increasing doses of ergotamine to relieve the migraine attacks. The only way to break this cycle is to discontinue the ergotamine. ${ }^{[18]}$ For approximately 10 years and eventually because of daily headaches, our patient had been taking 4-5 tablets ergotamine tartrate $(0.75 \mathrm{mg})$ daily. As the patient was thought to be addicted to ergotamine, that medication was terminated, and nonsteroidal naproxen sodium was started for headache relief.

In patients with angiospasm associated with ergotism, the extremities are seen to be pale and cold, peripheral pulses cannot be taken, and intermittent or chronic pain affects the extremities. The angiographic findings of widespread and segmental vasospasm are seen as regular vascular narrowing. The changes are generally symmetrical at an equivalent level in both extremities. ${ }^{[19]}$ The case reported here is different, in that having been exposed to trauma, only one extremity was affected, and it was determined that vasospasm was affecting all the arteries of that extremity. The toxic effects of ergotamine are more often seen from chronic usage, but acute toxicity can develop from a single excessive dose. The vasospastic effect of ergotamine is known to increase in some situations, such as fever, infection, poor nutrition, thyrotoxicosis, liver and renal insufficiency, and peripheral artery disease. ${ }^{[20,21]}$ To treat arterial vasospasm, it is necessary to inhibit reflex vasoconstrictor signals. To this end, an intra-arterial vasodilator, calcium channel blockers, beta-blockers, periarterial sympathetic block, local anesthetic infusion via epidural catheter, and preganglionic sympathectomy may be applied. In addition, anticoagulant treatment must be administered. In the current case, as soon as the diagnosis of arterial vasospasm had been made, the avmigran tablets, which he had been taking without our knowledge, were prohibited. IV glycerol trinitrate, IV heparin infusion and iloprost tromethamine infusion were started. An epidural catheter was applied, and epidural marcaine for sympathetic blockage and fentanyl infusion for analgesia were started.

After approximately two weeks of treatment, the patient was fit to undergo surgery. To reduce the surgical problems to a minimum, careful preoperative planning was essential regarding the choice of incision and techniques for fracture reduction and fixation. The vascular network of the long bones comes from feeder veins to the cortex internal two-thirds and from adjacent soft tissues to the external third of the cortical bone. Most studies have shown that classical plate fixation techniques significantly damage the vascular network feeding the bone. In our case, as the wound had been sutured medially and a single incision had been made, we applied a minimally invasive locked tibial plate (tibia - LISS) enabling fixation of both the medial and lateral plateau with no need for an additional supporting medial plate. ${ }^{[22]}$ The femoral head fracture was treated conservatively.

Having followed the analgesia and early rehabilitation program in the postoperative period, the patient was discharged without any problems. In our country, as ergotamine-derivative drugs are not subject to control, patients can easily obtain them unrecorded. Work is ongoing for similar drugs to come under the control of the Ministry of Health. That this clinical situation of traumatic angiospasm can arise 10 days posttrauma should be known and should be borne in mind for all trauma cases; it is necessary to take a detailed anamnesis for all the facts to come to light.

\section{Conflict of interest: None declared.}

\section{REFERENCES}

1. Keller U, Zocher R, Kleinkauf H. Biosynthesis of ergotamine in protoplasts of Claviceps puvpurea. Journal of General Microbiology 1980;118:485-94.

2. Pistorius MA, Connault J, Kalassy C, Goueffic Y, Planchon B. Acute posttraumatic ischemia of the limbs: algodystrophy or related syndrome? A prospective study on a series of 25 patients. Angiology 2008;59:301-5.

3. Kirtley JA. Arterial injuries in a theater of operations. Ann Surg 1945;122:223-34.

4. Thrush Q. Does work ergotamine for migraine? In: Warlow C, Garfield J, editors. Magement in the dilemmas of the neurological patient. Edinburgh: Churchill Livingstone; 1984. p. 106-13.

5. Merhoff GC, Porter JM. Ergot intoxication: historical review and description of unusual clinical manifestations. Ann Surg 1974;180:773-9.

6. Wilkinson M. Ergotamine headaches. In: Carroll JD, Pfaffenrath V, Sjaastad O, editors. Migraine and beta-blockkade. Uddevalla: Bohuslaeningens Boktryckeri; 1985. p. 176-9.

7. Meyler WJ. Side effects of ergotamine. Cephalalgia 1996;16:5-10.

8. Katzung BG. Histamine, serotonin and the ergot alkaloids. In: Katzung BG, editor. Basic and clinical pharmacology. 6th ed. New York, NY: McGraw Hill; 2007. p. 255-26.

9. Ala-Hurula V, Myllylä V, Hokkanen E. Ergotamine abuse: results of ergotamine discontinuation, with special reference to the plasma concentrations. Cephalalgia 1982;2:189-95.

10. Young JR, Humphries AW. Severe arteriospasm after use of ergotamine tartrate suppositories. Report of a case. JAMA 1961;175:1141-5.

11. Felix RH, Carroll JD. Upper limb ischaemia due to ergotamine tartrate. Practitioner 1970;205:71-2.

12. Feneley MP, Morgan JJ, McGrath MA, Egan JD. Transient aortic arch syndrome with dysphasia due to ergotism. Stroke 1983;14:811-4.

13. Weiner LS, Kelley M, Yang E, Steuer J, Watnick N, Evans M, et al. The use of combination internal fixation and hybrid external fixation in severe proximal tibia fractures. J Orthop Trauma 1995;9:244-50.

14. Watson JT, Wiss DA. Fractures of the proximal tibia and fibula. In: Rockwood C, Green D, Bucholz R, editors. Fractures in adults. 5th ed. Philadelphia: Lippincott Williams-Wilkins Company; 2001. p. 180141.

15. Boğa M. Akut ekstremite iskemisi. Türk Aile Hek Derg 2009;13:11-5.

16. Pope JE. The diagnosis and treatment of Raynaud's phenomenon: a practical approach. Drugs 2007;67:517-25.

17. Mills JL, Friedman EI, Taylor LM Jr, Porter JM. Upper extremity ischemia caused by small artery disease. Ann Surg 1987;206:521-8.

18. İnan L, Tulunay C, Güvener A. Ergotamin baş ağrısı ve Ergot bağımlılığı. 
Turkiye Klinikleri J Med Sci 1989;9:198-200.

19. McKiernan TL, Bock K, Leya F, Grassman E, Lewis B, Johnson SA, et al. Ergot induced peripheral vascular insufficiency, non-interventional treatment. Cathet Cardiovasc Diagn 1994;31:211-4.

20. Ghali R, De Léan J, Douville Y, Noël HP, Labbé R. Erythromycin-associated ergotamine intoxication: arteriographic and electrophysiologic analysis of a rare cause of severe ischemia of the lower extremities and associated ischemic neuropathy. Ann Vasc Surg 1993;7:291-6.

21. Fukui $S$, Coggia $M$, Goëau-Brissonnière $O$. Acute upper extremity ischemia during concomitant use of ergotamine tartrate and ampicillin. Ann Vasc Surg 1997;11:420-4.

22. Cole PA, Zlowodzki M, Kregor PJ. Treatment of proximal tibia fractures using the less invasive stabilization system: surgical experience and early clinical results in 77 fractures. J Orthop Trauma 2004;18:528-35.

\section{OLGU SUNUMU - ÖZET}

\section{Çoklu kırıklı bir olguda ergotamin kullanımına bağlı arteriyel vazospazm Dr. Abdullah Küçükalp, ${ }^{1}$ Dr. Kemal Durak, ${ }^{2}$ Dr. Muhammet Sadık Bilgen ${ }^{2}$}

${ }^{1}$ Suşehri Devlet Hastanesi, Ortopedi ve Travmatoloji Kliniği, Sivas ${ }^{2}$ Uludağ Üniversitesi Tıp Fakültesi, Ortopedi ve Travmatoloji Anabilim Dalı, Bursa

Ergotamin kullanımına bağlı gelişen vazospazm nadir görülen ve iyi bilinen bir komplikasyondur. Bu yazıda çoklu kırı̆ı olan ve travma sonrası I0. günde görülen ve aynı taraf alt ekstremitede tüm arterlerin etkilendiği arteriyospazm olgusu sunuldu. Bu olguda travma sonrası anjiyospazm ile karışabilecek olan ergotamin bağımlılığı ve aşırı doz egotamin kullanımı sonucu ortaya çıkan arteriyospazm; epidural kateter aracılığı ile marcain infüzyonu, intravenöz yolla heparin, iliomedin ve nitronal infüzyonu ile tedavi edildi. Tüm arteryel vazospazm saptanan travma olgularında bu klinik durum akılda tutulmalı ve hastadan anamnez alınırken ergotamin kullanımı mutlaka sorgulanmalıdır.

Anahtar sözcükler: Ergotamin bağımlıı̆ı, migren, çoklu kırık, vazospazm.

Ulus Travma Acil Cerr Derg 2013; 19(5):475-479 doi: 10.5505/tjtes.20।3.63626 